\title{
RESTATEMENTS AND ADJUSTEMNTS IN ELABORATION OF CONSOLIDATED FINANCIAL STATEMENTS
}

\author{
Sorin-Constantin Deaconu ${ }^{l}$
}

\begin{abstract}
This paper deals interdisciplinary with issues related to accounting's groups of companies, offering solutions or answers to immediate problems of accounting practice, and propose viable theoretical generalizations at least concerning the ongoing development of the participating entities on consolidation. Thus, the accountant will be able to verify the correct elaboration of the consolidated financial statements taking into account the profit accrued to third party.
\end{abstract}

Key words: consolidated financial statements, accounting, accounting restatements, minor interests

JEL codes: $M$ 41, O 10

\section{Introduction}

The consolidated financial statements could be defined as the financial statements of a group presented as those of a single economic entity. An enterprise group consists of a parent (control) and one or more subsidiaries (controlled). The question that arises is when a firm is controlled by a parent to become a subsidiary? In this International Accounting Standard 27 "Consolidated Financial Statements and Accounting for Investments in subsidiaries" defines the concept of control as the authority to conduct financial and operating policies of an enterprise so as to obtain benefits from its activities (paragraph 6).

The scientific research requires, besides an important resource allocation, a personal commitment.

Because in the chosen field for research the literature is not very rich, especially at national level, we mention as individual elements of motivation for the research the following: the need for learning, the need for personal development, the need to improve a job or a career, the need for social recognition, the satisfaction derived from solving practical problems faced by business groups, stepping into "not-cleared" areas.

Please note that for the paper elaboration has not been used a methodology designed as an absolute pattern, but I appealed to the combination of methods, research tools and techniques taken from economic theory.

\section{Literature review}

The documentation work was performed by:

- Revising of the specialty literature. In this regard we have made the accent on the research work, on the specialty literature documentation related to the previous researches and also on documentation concerning the activity of different economy normalization organisms. Our research work based on the specialty literature, on the analyse of the financial reporting standards has as aim to go beyond the personalization of the accounting registration opinions, hypothesis and models in order to test the reflecting of the theoretical concepts over the practical work in elaboration of consolidated financial statements.

\footnotetext{
1 „1 Decembrie 1918” University, Faculty of Science, Alba Iulia, Romania,e-mail: deaconu_sorin@uab.ro.
} 
- Studying the normative and other documents. This method involves analyzing the documents in question using some parameters set out in relation to the scope and the objectives of the research. For the present paper were studied documents such as: Order no. $3055 / 2009$ concerning the approval of the accounting regulations according with the European Directive, The accounting law no. 82/1991, republished, with further amendments and completions. The scope of the study was to highlight the viewpoint of the Romanian lawmaker and eventually to bring some improvement proposals for the consolidated financial statements.

\section{Research methodology}

Specifically, the research methodology was customized as follows: - documentation and archival study. A golden rule for accounting said that any economic-financial transaction, with certain exceptions, must be based on a supporting document. Thus, I have studied a series of documents, namely: accounting records, financial statements, supporting documentation (the asset sheet, receiving records, etc.);

- field study through which was done a direct confrontation with the reality of the group entities;

- phenomenological approach by which a descriptive study of the processes, phenomena, facts and different accounting situations in their changes in time and space is achieved; - qualitative approach: involves a privacy intrusion into real or imaginary structures through interpretation, the naturalistic explanation, understanding, comprehension. Thus is possible a generalization by moving from individual to general calling for induction.

\section{Accounting restatements and adjustments}

Taking into consideration the fact that the main processes of European compatibility of Romania in this period (especially as "coverage" of international economic and financial crisis), are economic convergence (the specialty literature refers to accounting convergence, harmonization, compliance etc.) and country's sustainable development, we consider that is crucial for enterprise groups to proliferate and develop.

In order to elaborate the consolidated financial statements of an enterprise group consisting of a parent (A) and its subsidiary (B) some adjustments are necessary (we preset only a part of these adjustments):

A) Elimination of shares in the entities included in consolidation and the corresponding fractions of the net assets.

In this stage is necessary to resolve the following issues:

- enhancing participation and treatment of consolidation differences;

- inclusion of minority interests.

a. In terms of enhancing the participation and treatment of consolidation differences is required the following:

- the participation value of the parent in subsidiary B is registered in the balance sheet of the parent company with the amount of ...............................................................................19,000,000 lei - the capital and reserves at 31.12.YYYY held by the parent at company B (70\% *

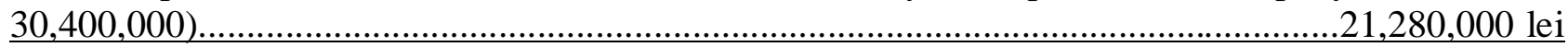
- negative difference of consolidation 2,280,000 lei

Accounting adjustments

\begin{tabular}{|l|c|c|}
\hline \multicolumn{1}{|c|}{ Indicators } & Adjustments & Adjustments \\
\hline Capital and reserves of B subsidiary & $(-) 21,280,000$ & \\
\hline Participation held by the parent at B subsidiary & & $(-) 19,000,000$ \\
\hline Consolidation reserve & & $(+) 2,280,000$ \\
\hline
\end{tabular}


b. inclusion of minority interests. Concerning this item, the parent shall incorporate in the consolidated balance sheet the interests of minority shareholders in a position called "third-party capital and reserves". Similarly, the profit/loss share of B subsidiary accrued to minority shareholders must be registered in a field in the income statement called "third party profit (loss) for the period".

Determination of B subsidiary share capital and reserves accrued for the third party is made according to the following reasoning:

$$
30.400 .000 * 30 \%=9,120,000 \text { lei }
$$

The amount of 9,120,000,000 lei represents minority interests held by other shareholders in the B subsidiary portfolio. In this review should be carried out following adjustment into the balance sheet:

Table no. 2 .

Accounting adjustments

\begin{tabular}{|l|c|c|}
\hline \multicolumn{1}{|c|}{ Indicators } & Adjustments & Adjustments \\
\hline Capital and reserves of B subsidiary & $(-) 9,120,000$ & \\
\hline $\begin{array}{l}\text { Capital and reserves of third party } \\
\text { (minority interests) }\end{array}$ & & (+) $9,120,000$ \\
\hline
\end{tabular}

As mentioned above there must be determined the share of B subsidiary profit accrued to minority shareholders B. In this respect we will perform the following calculation:

- The share of third parties.

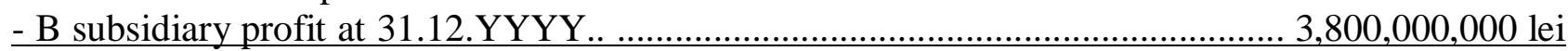
- Third party profit...................................... 3,800,000*30\% = 1,140,000 lei The amount of 1,140,000 lei is owned by shareholders other than the parent in the B subsidiary's profit and should therefore be made the following adjustments, both in the balance sheet and profit and loss account:

Table no. 3 .

Accounting adjustments

\begin{tabular}{|l|c|c|}
\hline \multicolumn{1}{|c|}{ Indicators } & Adjustments & Adjustments \\
\hline B subsidiary profit & $(-) 1,140,000$ & \\
\hline The profit accrued for the third party & & $(+) 1,140,000$ \\
\hline
\end{tabular}

B) Eliminating mutual debits and credits. Eliminate the amount of 228 thousands lei from the consolidated balance sheet relating to the sale and purchase of raw materials, an amount that is a debt of B subsidiary to the parent company. This adjustment is made within the balance sheet.

Table no. 4.

Accounting adjustments

\begin{tabular}{|l|c|c|}
\hline \multicolumn{1}{|c|}{ Indicators } & Adjustments & Adjustments \\
\hline Debts to the parent company & $(-) 228,000$ & \\
\hline Loans for B controlled society & & $(-) 228,000$ \\
\hline
\end{tabular}

C. Elimination of profit / loss on the operation of the internal transfer of equipment from the B subsidiary to the parent with a profit of 380 thousands lei. The sale and purchase contract of property within an enterprise group presents specific consolidation problems. It will be necessary to 
remove all equipment depreciations calculated at historical cost of 836 thousands lei (this adjustment will be made in the balance sheet):

Table no. 5 .

Accounting adjustments

\begin{tabular}{|c|c|c|}
\hline Indicators & Adjustments & Adjustments \\
\hline Equipment & $\begin{array}{r}\text { (historical cost) } \\
(+) 836.000\end{array}$ & $\begin{array}{l}\text { (sale price) } \\
(-) 760,000\end{array}$ \\
\hline Calculated depreciation & & $\begin{array}{r}\text { (+) } 456,000 \\
(+) 7,600 \\
\end{array}$ \\
\hline Profit A & $\begin{array}{r}\text { (-) } 380,000 \\
(-) 7,600\end{array}$ & \\
\hline
\end{tabular}

It becomes imperative to adjust also the profit or loss account as a result of the above operation (decreasing the profit of parent company A with a value of 387.6 thousands lei and eliminate the added value of 380 thousands lei registered by the B controlled company following the sale of equipment):

Table no. 6.

Accounting adjustments

\begin{tabular}{|l|r|r|}
\hline \multicolumn{1}{|c|}{ Indicators } & \multicolumn{1}{c|}{ Adjustments } & \multicolumn{1}{c|}{ Adjustments } \\
\hline Added value & $(-) 380,000$ & \\
\hline Calculated depreciation & $(+) 7,600$ & \\
\hline Profit A & & $(-) 380,000$ \\
& & $(-) 7,600$ \\
\hline
\end{tabular}

D. Elimination of dividends distributed by the B subsidiary to the parent in amount of 760 thousands lei.

a. the adjustment in the balance will lead to the formation of a specific position called "reserve from the consolidated profits":

Table no. 7.

\begin{tabular}{|l|c|c|}
\hline \multicolumn{1}{|c|}{ Indicators } & Adjustments & Adjustments \\
\hline Parent (A) profit & $(-) 760,000$ & \\
\hline Reserve from consolidated profits & & $(+) 760,000$ \\
\hline
\end{tabular}

b. adjustment in the profit and loss account will reduce the income from dividends obtained by the parent company:

Table no. 8 .

Accounting adjustments

\begin{tabular}{|l|c|c|}
\hline \multicolumn{1}{|c|}{ Indicators } & Adjustments & Adjustments \\
\hline Dividends A & $(-) 760,000$ & \\
\hline Profit A & & $(-) 760,000$ \\
\hline
\end{tabular}

E. Elimination of mutual shareholdings. In this case the controlled company B has a participation in the parent company of 3,800,000 lei. Therefore in order to present the enterprise group statement the following operations are needed: 
a. transferring the participation held by subsidiary in own shares (correction is made in the balance sheet):

Table no. 9.

Accounting adjustments

\begin{tabular}{|l|c|c|}
\hline \multicolumn{1}{|c|}{ Indicators } & Adjustments & Adjustments \\
\hline Own shares & $(+) 3,800,000$ & \\
\hline Participation in the parent company A & & $(-) 3,800,000$ \\
\hline
\end{tabular}

b. creating a reserve for own shares for an amount of 3,800,000 lei (rectification is carried in the balance sheet):

Table no. 10.

Accounting adjustments

\begin{tabular}{|l|c|c|}
\hline \multicolumn{1}{|c|}{ Indicators } & Adjustments & Adjustments \\
\hline Statutory reserve A & $(-) 3,800,000$ & \\
\hline Reserve for own shares & & $(+) 3,800,000$ \\
\hline
\end{tabular}

\section{Acknowledgements}

Note that in drafting the paper documentation was made both in terms of theory, but in practical terms. Theoretically, we made reference to a series of regulations in force, but I did call and literature specialty, including international standards developed by the IASB. Basically, documentation was made at a series of entities, which we want to bring them thanks for our willingness to provide a series of data necessary for our scientific approach. And we want to Thank You University „1 Decembrie 1918” for giving us the opportunity to present our paper.

\section{Conclusions}

It becomes obvious that the consolidated result is not the sum of the individual results of consolidated companies.

In order to verify the correctness of calculations the following reasoning can be done:

(+) Result before taxation. 21,201,644 lei

(-) Income Tax $9,873,920$ lei

$=$ Net profit $(A+B)+$ profit accrued to third party. $11,327,724$ lei

This is the correlation through which the accountant expert can check the correctness of financial statements elaboration in general and of the profit and loss account in particular.

\section{References}

1. Albu, N., Albu, C. N., Bunea, S., Calu D. A., Girbina, M. M., 2011. A story about IAS/IFRS implementation in Romania, Journal of Accounting in Emerging Economies, volume 1, pp. 76 100.

2. Feleagă, N., Feleagă, L., 2007. Contabilitate consolidată. O abordare europeană şi internaţională. Bucharest, Publisher Economică.

3. Gaa, J.C., 2009. Corporate Governance and the Responsibility of the Board of Directors for Strategic Financial Reporting, Journal of Business Ethics, volume 90, pp. 179-197.

4. The Order no. 3055/2009 concerning the approval of the accounting regulations according with the European Directive, Official Journal no. nr. 766 bis/2009.

5. The accounting law no. 82/1991, republished, with further amendments and completions, Official Journal no. 454/2008. 